Original Research Paper

\title{
Vegetative Growth of Green Eggplant Due to Treatment of Vermicompost and NPK Fertilizer
}

\author{
Ahmad Raksun*, Moh. Liwa Ilhamdi, I wayan Merta, I Gde Mertha \\ Program Studi Pendidikan Biologi, FKIP Universitas Mataram, Indonesia
}

\author{
Article History \\ Received : August 28 ${ }^{\text {th }}, 2021$ \\ Revised : August 30 ${ }^{\text {th }}, 2021$ \\ Accepted : September $15^{\text {th }}, 2021$ \\ Published : September $30^{\text {th }}, 2021$ \\ *Corresponding Author: \\ Ahmad Raksun, \\ Pendidikan Biologi, FKIP Unram, \\ Mataram, Indonesia \\ Email: ahmadunram@unram.ac.id
}

\begin{abstract}
Green eggplant is native to the tropics. Green eggplant is one of the most popular vegetable ingredients in Indonesia. The abundance various macro and micro nutrients in the growing media affected the growth and yield of green eggplant. Study on vegetative growth of green eggplant due to the influence of the aplication of vermicompost and NPK fertilizer has been completed from April to August 2021. This study aims to determine: (1) vegetative growth of green eggplant due to vermicompost treatment, (2) green eggplant vegetative growth due to NPK fertilizer treatment, (3) green eggplant vegetative growth due to interaction of vermicompost and NPK fertilizer treatment. This research was conducted in a factorial completely randomized design with three replications. The first factor is the application of NPK fertilizer which consists of 4 levels and the second factor is the treatment of vermicompost which consists of 5 levels. Anova test is used for research data analysis. In the study obtained result: (1) treatment of NPK fertilizer with different doses significantly effected the number of leaves, stem diameter, leaf length, and stem height of green eggplant. The optimum dose of NPK fertilizer was 2 grams for one plant, which produced the number of leaves, diameter stems, leaf length and stem height of green eggplant were better than treatments at other doses. (2) The treatment of vermicompost had a significant effect on the number of leaves, stem diameter, leaf blade length, and stem height of green eggplant, the optimum dose of vermicompost was $1.8 \mathrm{~kg}$ for $1 \mathrm{~m} 2$ of agricultural land, resulting in stem diameter, number of leaves, leaf length and green eggplant stem height was better than other treatments (3) the interaction of vermicompost and NPK fertilizer had no significant effect on stem diameter, number of leaves, leaf length and stem height of green eggplant
\end{abstract}

Keywords: effect of vermicompost and NPK fertilizer, green eggplant growth.

\section{Pendahuluan}

Tanaman terung diperkirakan berasal dari Asia yaitu Indonesia, India dan Myanmar. Perkembangan budidaya terung yang paling pesat terjadi di Asia Tenggara termasuk di Indonesia (Mashudi, 2007). Tanaman terung termasuk kelompok tanaman dikotil, berakar tunggang dengan akar pokok yang menembus tanah yang panjangnya mencapai $80 \mathrm{~cm}$ (Aidah, 2020). Buah terung adalah salah satu bahan sayuran yang digemari oleh masyarakat Indonesia dan dikenal oleh semua lapisan masyarakat baik di perkotaan maupun di pedesaan. Buah terung memiliki citarasa yang enak, dapat diolah menjadi sayuran lodeh, opor terung, terung asinan dan terung manisan (Mashudi, 2007).

Varietas terung yang cukup banyak dikembangkan di Indonesia adalah terung hijau (Aidah, 2020). Pemupukan merupakan salah satu faktor penting untuk meningkatkan produktivitas tanaman terung (Maghfoer, 2018). Pada saat sekarang ini petani di Indonesia sering melakukan pemupukan menggunakan pupuk kimia secara berlebihan dan melakukan pembakaran jerami padi setelah panen. Penggunaan pupuk kimia secara berlebihan dan pembakaran jerami padi berdampak negatif terhadap menurunnya bahan organik tanah, 
serta menurunnya kemapuan tanah menyimpan dan melepaskan hara dan air bagi tanaman. Untuk mengrangi dampak yang tidak diinginkan dari penggunaan pupuk kimia yang berlebihan maka penggunaan pupuk kimia perlu dikombinasikan dengan pupuk organik (Astuti et al, 2016). Manahan et al (2016) menguraikan bahwa pupuk organik yang dapat dimanfaatkan adalah kascing. Kascing merupakan kotoran cacing tanah yang bertekstur halus. Kotoran tersebut merupakan hasil olahan bahan organik dan beberapaa unsur mineral esensial dari tanah yang dimakan oleh cacing. Lebih lanjut (Manahan et al (2016) menjelaskan bahwa kascing memberikan manfaat bagi tanaman diantaranya menyuburkan dan menggemburkan tanah sehingga cocok sebagai media tanam, merangsang pertumbuhan akar, batang dan daun, merangsang pertumbuhan bunga, mempercepat panen serta meningkaatkan produktivitas.

Perlakuan vermicompost dan bioaktivator berdampak signifikan terhadap parameter pertumbuhan tanaman sawi dengan hasil yang lebih baik dibandingkan dengan kontrol (Wahyudin dan Irawan, 2019). Aplikasi pupuk kascing berpengaruh nyata meningkatkan jumlah buah per tanaman dan tinggi tanaman okra dan bawang merah yang ditanam dengan sistem tumpang sari (Hidayatullah et al, 2020). Aplikasi pupuk kascing berpengaruh signifikan terhadap meningkatnya tinggi tanaman, jumlah daun dan volume tajuk tanaman selada. Dosis terbaik pupuk kascing untuk tanaman selada adalah 50 gram per polybag (Dosem et al, 2018). Merujuk pada hasil penelitian tersebut maka dilakukan penelitian tentang pertumbuhan vegetatif tanaman terung hijau akibat perlakuan pupuk kascing dan pupuk NPK. Penelitian ini bertujuan untuk mengetahui (1) pengaruh kascing terhadap pertumbuhan terung hijau pada aplikasi dengan dosis yang berbeda, (2) pengaruh pupuk NPK terhadap pertumbuhan terung hijau pada aplikasi dengan dosis yang berbeda, (3) pertumbuhan vegetatif tanaman terung hijau sebagai dampak interakasi perlakuan kascing dan pupuk NPK.

\section{Bahan dan Metode}

Bahan-bahan yang digunakan adalah: pupuk kascing, air sumur. benih terung hijaau, pupuk NPK, polybag bibit, lapisan atas (topsoil) tanah sawah, pupuk NPK mutiara, jaring paranet, kertas transparan, pagar anyaman bambu, tali rapia dan ajir bambu. Adapun alat-alat yang digunakan yaitu: hand spreyer, mesin pompa air, karung nilon, sabit, cangkul, parang, ember plastik, meteran, timbangan, gelas ukur dan alat tulis menulis. Penelitian ini dilaksanakan dalam 11 tahapan: (1) penyiapan alat dan bahan yang diperlukan, (2) pembibitan tanaman terung hijau menggunkan polybag bibit warna hitam (3) pengadaan pupuk NPK dan kascing, (4) mengolah lahan percobaan, (5) perlakuan pupuk kascing pada lokasi penelitian 12 hst, (6) penanaman bibit terung hijau, (7) pengairan lahan percobaan sekali dalam 12 hari, (8) perlakuan pupuk NPK pada umur 15 hari, 25 hari dan 35 hari setelah tanam, (9) pemberantasan hama dan penyakit tanaman, (10) pengambilan data penelitian, (11) analisis data peneilitian. Data pertumbuhan tanaman diolah dengan uji varians (Teutenburg. and Shalabh, 2009).

Penelitian ini dilaksanakan dengan rancangan acak lengkap faktorial dengan 3 ulangan. Perlakuan pertama adalah pemberian pupuk NPK yang terdiri atas 4 aras perlakuan yaitu: $\mathrm{N}_{0}=0$ gram pupuk NPK, $\mathrm{N}_{1}=1$ gram pupuk NPK, $\mathrm{N}_{2}=2$ gram pupuk NPK, dan $\mathrm{N}_{3}=3$ gram pupuk NPK. Perlakuan faktor pertama dilaksanakan ketika terung hijau berusia 15, 25 dan 35 hari setelah tanam. Perlakuan berikutnya adalah aplikasi kascing dengan 5 aras aplikasi, yaitu: $\mathrm{K}_{0}=$ perlakuan $0 \mathrm{~kg}$ pupuk kascing, $\mathrm{K}_{1}$ = perlakuan $0,6 \mathrm{~kg}$ pupuk kascing, $\mathrm{K}_{2}=$ perlakuan $1,2 \mathrm{~kg}$ pupuk kascing, $\mathrm{K}_{3}=$ perlakuan 1,8 $\mathrm{kg}$ pupuk kascing, $\mathrm{K}_{4}=$ perlakuan 2,4 kg pupuk kascing (Gomez dan Gomez. 1991). Perlakuan pupuk kascing dilakukan dengan cara ditebar secara pada tanah lapisan atas (topsoil).

\section{Hasil dan Pembahasan}

\section{Jumlah Daun}

Jumlah daun tanaman terung hijau yang diukur 50 hari setelah tanam berbeda beda pada setiap kombinasi perlakuan. Sacara umum jumlah daun bertambah seiring dengan penambahan kadar pupuk kascing dan pupuk NPK yang diaplikasikan. Diperoleh total daun terbanyak $=48$ helai daun yang ditemukan pada kombinasi perlakuan $1,8 \mathrm{~kg}$ pupuk kascing per $1 \mathrm{~m}^{2}$ lahan pertanian dan 2 gram pupuk NPK per tanaman. Adapun jumlah daun terkecil adalah 41 helai daun, ditemukan pada kontrol perlakuan. Data jumlah daun terung hijau pada umur 
50 hari setelah tanam akibat perbedaan kadar pupuk kascing dan pupuk NPK adalah sebagai berikut.

Tabel 1. Data Jumlah Daun Terung Hijau Setelah Pemberian Pupuk NPK dan Kascing yang diukur 50 HST

\begin{tabular}{|c|c|c|c|}
\hline Kombinasi & $\begin{array}{l}\text { Jumlah daun } \\
\text { (helai) }\end{array}$ & Kombinasi & $\begin{array}{c}\text { Jumlah daun } \\
\text { (helai) }\end{array}$ \\
\hline NoK0 & 41 & $\mathrm{~N}_{2} \mathrm{~K} 0$ & 43 \\
\hline N0K1 & 42 & $\mathrm{~N}_{2} \mathrm{~K}_{1}$ & 43 \\
\hline NoK2 & 43 & $\mathrm{~N}_{2} \mathrm{~K}_{2}$ & 44 \\
\hline NoK3 & 44 & N2K3 & 48 \\
\hline $\mathrm{N}_{0} \mathrm{~K} 4$ & 43 & $\mathrm{~N}_{2} \mathrm{~K} 4$ & 46 \\
\hline $\mathrm{N}_{1} \mathrm{~K}_{0}$ & 43 & $\mathrm{~N}_{3} \mathrm{~K}_{0}$ & 41 \\
\hline $\mathrm{N}_{1} \mathrm{~K}_{1}$ & 44 & $\mathrm{~N}_{3} \mathrm{~K}_{1}$ & 43 \\
\hline $\mathrm{N}_{1} \mathrm{~K}_{2}$ & 45 & N3K2 & 43 \\
\hline N1K3 & 46 & N3K3 & 45 \\
\hline N1K4 & 44 & N3K4 & 43 \\
\hline
\end{tabular}

Uji Anova memberikan hasil bahwa perbedaan dosis kascing berpengaruh signifikan terhadap jumlah daun tanaman terung hujau. Aplikasi pupuk NPK berdampak signifikan terhadap jumlah daun terung hijau. Jumlah daun tanaman terung hijau tidak bebeda nyata akibat interaksi aplikasi kascing dan pupuk NPK. Pupuk kascing adalah pupuk kompos yang dihasilkan dengan bantuan cacing tanah. Adanya peningkatan jumlah daun terung hijau akibat perlakuan pupuk kascing dimungkinkan karena kascing mengandung unsur hara makro dan mikro yang sangat diperlukan dalam pembentukan dan pertumbuhan daun tanaman. Mulat (2003) menjelaskan bahwa pupuk kascing mengandung unsur hara yang lengkap baik unsur hara makro maupun unsur hara mikro yang berguna bagi pertumbuhan dan perkembangan tanaman. Analisis unsur hara yang terkandung dalam kascing Eisenia foetida memberikan hasil bahwa pupuk kascing mengandung unsur hara yang meliputi Nitrogen $=0,63 \%$, Fluor $=0,35 \%$, Kalium 0,20\%, Calsium 0,235, Magnesium = $0,26 \%$, Natrium $=0,07 \%$, Seng $=0,007 \%$ dan Mangan $=0,003 \%$. Demikian juga Elfayetti (2017) menjelaskan bahwa kascing yang diproduksi dengan memanfaatkan cacing tanah spesies Lumbricus rubeltus yang diberi pakan limbah kangkung dan bayam memiliki kandungan nutrient $\mathrm{N}, \mathrm{P}$ dan K. Nutrient ini diperlukan dalam jumlah banyak untuk mendukung pembentukan daun terung hijau.

Perlakuan pupuk NPK dapat meningkatkan jumlah daun tanaman terung hijau. Penelitian pada tanaman lain memberikan hasil yang serupa dengan hasil penelitian ini. Firmansyah et al (2017) menemukan bahwa perlakuan pupuk NPK mengakibatkan penambahan jumlah daun tanaman terung. Penambahan jumlah daun terjadi karena unsur hara $\mathrm{N}, \mathrm{P}$ dan $\mathrm{K}$ merupakan unsur hara utama yang dibutuhkan untuk mendukung pertumbuhan vegetatif terung hijau. Selanjutnya penelitiaan pada tanaman jagung manis menunjukkan bahwa aplikasi pupuk NPK dapat meningkatan jumlah daun jagung manis. Tinggi tanaman jagung manis pada perlakuan pupuk NPK dengan dosis 6 gram menghasilkan tinggi tanaman paling tinggi dibandingkan perlakuan lainnya (Raksun et al, 2021). Jumlah daun jagung manis meningkat akibat perlakuan pupuk NPK mutiara. Perlakuan 180 gram pupuk NPK mutiara per petak memberikan hasil rata-rata 15,65 helai daun, lebih tinggi dibandingkan kontrol. Dosis tersebut merupakan dosis terbaik untuk tanaman jagung manis (Assagaf, 2017). Jumlah daun tanaman sawi sendok mengalami peningkatan signifikan akibat perlakuan pupuk NPK. Perlakuan 2 gram pupuk NPK per tanaman merupakan perlakuan optimum untuk memacu pertumbuhana sawi sendok (Raksun et al, 2020). Kombinasi pemberian pupuk NPK dan sumber tunas memiliki dampak signifikan terhadap meningkatnya jumlah daun nenas. Pemberian pupuk NPK juga meningkatkan parameter pertumbuhan tanaman nenas yang lainnya (Cahyono et al, 2014). Perlakuan pupuk NPK secara signifikan dapat meningkatkan jumlah daun, kacang hijau. Selain itu perlakuan pupuki NPK juga 
memacu pertumbuhan batang dan daun dan memacu peningkatan hasil tanaman (Murdaningsih and Kramat, 2014).

\section{Diameter Batang}

Hasil pengukuran diameter batang yang dilakukan 60 hari pasca penanaman menggambarkan bahwa diameter batang terung hijau bervariasi sesuai dengan dosis pupuk kascing dan pupuk NPK yang diberikan. Diameter batang terung hijau tertinggi adalah $20 \mathrm{~mm}$ dihasilkan dari aplikasi 2 gram pupuk NPK untuk setiap unit percobaan dan 18 ton kascing untuk 1 hektar sawah. Diameter batang terendah sebesar $14 \mathrm{~mm}$ ditemukan pada kontrol percobaan. Diameter batang tanaman terung hijau 60 hari setelah tanam diukur menggunakan mistar. Hasilnya dapat dilihan pada tabel dibawah ini.

Tabel 2. Data Diameter Batang Terung Hijau Setelah Aplikasi Pupuk Kascing dan Pupuk NPK 60 HST

\begin{tabular}{|c|c|c|c|}
\hline Kombinasi & $\begin{array}{c}\text { Diameter } \\
\text { Batang }(\mathrm{mm})\end{array}$ & Kombinasi & $\begin{array}{c}\text { Diameter } \\
\text { Batang }(\mathrm{mm})\end{array}$ \\
\hline N0K0 & 14 & $\mathrm{~N} 2 \mathrm{~K} 0$ & 16 \\
\hline N0K1 & 16 & $\mathrm{~N}_{2} \mathrm{~K}_{1}$ & 17 \\
\hline N0K2 & 17 & N2K2 & 17 \\
\hline N0K3 & 18 & N2K3 & 20 \\
\hline N0K4 & 18 & N2K4 & 19 \\
\hline N1K0 & 17 & N3K0 & 15 \\
\hline N1K $_{1}$ & 17 & $\mathrm{~N}_{3} K_{1}$ & 16 \\
\hline N1K2 & 17 & N3K2 & 17 \\
\hline N1K3 & 19 & N3K3 & 18 \\
\hline N1K4 & 18 & N3K4 & 18 \\
\hline
\end{tabular}

Uji anova memberikan hasil bahwa perlakuan kascing berdampak signifikan pada diameter batang terung hijau, Aplikasi pupuk NPK berdampak signifikan pada peningkatan diameter batang terung hijau. Tidak ada peningkatan diameter batang yang signifikan akibat interaksi perlakuan pupuk NPK dengan pupuk kascing. Meningkatnya diameter batang akibat pemberian kascing terjadi karena kascing mengandung bahan organik yang mampu meningkatkan kondisi fisika, biologi dan kimia lahan. Utama et al (2017) menjelaskan bahwa rabuk alami yang diproduksi dengan bantuan cacing tanah memiliki kondisi fisik, kimia dan biologi yang lebih unggul dari pada rabuk organik yang dihasilkan tanpa bantuan cacing tanah. Kascing adalah pupuk non kimia sintetik yang diproduksi melalui dedradasi bahan organik oleh cacing tanah, dapat memperbaiki kesuburan tanah, menambah mikrobia bermanfaat dan meningkatkan nutrient tersedia yang diperlukan tumbuhan. Afandi et al (2015) menjelakan bahwa aplikasi berbagai bahan organik seperti kompos berpengaruh signifikan terhadap sifat kimia tanah, serapan Nitrogen, fosfor dan kalium di tanaman dan umbi serta pertumbuhan dan produksi ubi jalar. Selanjutnya Gusmini et al (2008). Menjelaskan bahwa aplikasi bahan organik dapat mempertinggi jumlah hara makro $\mathrm{N}, \mathrm{P}$ dan $\mathrm{K}$ lahan. Tingkat penambahan unsur tersebut dipengaruhi oleh macam bahan organik yang diaplikasikan.

Aplikasi pupuk NPK berdampak signifikan pada diameter batang tanaman terung hijau. Adanya pengaruh nyata perlakuan pupuk NPK pada diameter batang juga didapatkan oleh beberapa penelti. Aplikasi pupuk NPK dapat meningkatkan diameter batang bibit kelapa sawit umur 8 bulan (Adnan et al, 2015). Aplikasi pupuk NPK pada dosis 22,5 gram per plot menghasilkan diameter batang jagung tertinggi dan berbeda nyata dengan perlakuan 0 gram per plot (Irawan et al, 2019). Pemberian pupuk NPK mutiara berdampak signifikan pada peningkatan diameter batang tanaman melon. Dosis optimum adalah $5 \mathrm{~g}$ pupuk NPK untuk 1 batang yang menghasilkan diameter batang terting gi sebesar 11,86 mm (Ayu et al, 2017). Penggunaan pupuk NPK berdampak signifikan terhadap pertumbuhan tanaman jagung dengan absorbsi pupuk NPK optimal berlangsung pada 28 
hari sampai dengan 35 hari pasca penanaman jagung. (Febianas et al, 2016).

\section{Panjang Helaian Daun}

Rerata panjang helaian daun terung hijau bervariasi pada setiap unit percobaan. Data yang diperoleh memberikan hasil bahwa panjang daun terung hijau bertambah seiring bertambahnya kadar perlakuan pupuk NPK dan kascing pada masingmasing kombinasi perlakuan. Pada unit percobaan dengan pemberian 2 gram pupuk NPK dan $1,8 \mathrm{~kg}$ pupuk kascing diperoleh panjang helaian daun tertinggi sebesar $32 \mathrm{~cm}$. panjang daun terendah adala $26 \mathrm{~cm}$ ditemukan pada tanaman terung hijau tanpa pemberian pupuk kascing dan pupuk NPK. Data hasil pengukuran panjang daun terung hijau setelah perlakuaan pupuk NPK yang dikombinasikan dengan kascing disajikan pada tabel berikut.

Tabel 3. Data Panjang Helaian Daun Terung Hijau Setelah Aplikasi Pupuk NPK dan Kascing 60 HST

\begin{tabular}{|c|c|c|c|}
\hline Kombinasi & $\begin{array}{c}\text { Panjang Daun } \\
(\mathrm{cm})\end{array}$ & Kombinasi & $\begin{array}{c}\text { Panjang Daun } \\
(\mathrm{cm})\end{array}$ \\
\hline N0K0 & 26 & $\mathrm{~N} 2 \mathrm{~K} 0$ & 28 \\
\hline NoK1 & 27 & $\mathrm{~N}_{2} \mathrm{~K}_{1}$ & 29 \\
\hline $\mathrm{N}_{0} \mathrm{~K}_{2}$ & 27 & $\mathrm{~N}_{2} \mathrm{~K}_{2}$ & 29 \\
\hline NoK3 & 28 & N2K3 & 32 \\
\hline NoK4 & 28 & N2K4 & 31 \\
\hline $\mathrm{N}_{1} \mathrm{~K}_{0}$ & 27 & N3K0 & 28 \\
\hline $\mathrm{N} 1 \mathrm{~K}_{1}$ & 28 & $\mathrm{~N}_{3} \mathrm{~K}_{1}$ & 28 \\
\hline N1K2 & 29 & N3K2 & 29 \\
\hline N1K3 & 29 & N3K3 & 30 \\
\hline N1K4 & 29 & N3K4 & 30 \\
\hline
\end{tabular}

Analisis varians memberikan hasil bahwa pemberian kascing memiliki dampak signifikan terhadap peningkatkan panjang helaian daun terung hijau. Pemberian pupuk NPK berdampak signifikan pada kenaikan panjang helaian daun terung hijau. Tidak terdapat kenaikan panjang helaian daun yang signifikan akibat interaksi perlakuan pupuk NPK dan kascing. Adanya peningkatan ukuran helaian daun terung hijau karena pengaruh aplikasi kascing disebabkan oleh adanya peningkatan unsur hara dalam tanah. Aplikasi kascing teramati menaikkan nitrogen tersedia tanah dimana kenaikan terbesar terjadi pada aplikasi kascing 30 kwintal perhektar, menaikkan absorbsi nitrogen tanaman dimana kenaikan terbaik diperoleh pada perlakuan kascing 30 kwintal per hektar tampa pupuk anogganik, sebesar 0,714 g per tumbuhan, meningkatkan nitrogen total tanah dengan peningkatan terbaik didapatkan pada perlakuan kascing 30 kwintal perhektar yang dikombinasikan bersama urea 2 kwintal per hektar, 1 kwintal SP36 untuk 1 hektar, setengah kwintal KCL setiap hektar, sebesar $0,30 \%$ dan meningkatkan Nitrogen jaringan tanaman dengan kenaikkan maksimum diperoleh pada aplikasi kascing 30 kwintal setiap hektar, tanpa pupuk kimia sintetik, sebesar 0,30\% (Khairani et al, 2010). Perlakuan 35,0 ton per hektar kascing dapat meningkatkan nitrogen pada lahan sebesar $1,41 \%$, phosphor tersedia pada, $3,11 \%$ carbon-organik lahan dan $12,89 \%$ total populasi mikroorganisme tanah, serta meningkatkan $8,35 \%$ berat tajuk kering. Perlakuan 200 kwintal per hektar kascing mampu menaikkan $8,79 \%$ berat basah tanaman, $1,33 \%$ total daun, dan meningkatkan hasil tanaman sawi hijau (Sinda et al, 2015).

Perlakuan pupuk NPK dapat meningkatkan panjang helaian daun tanaman terung hijau. Data serupa diperoleh pada tanaman yang lain. Penelitian pada tanaman kangkung darat ditemukan bahwa aplikasi pupuk NPK dapat meningkatkan panjang daun kangkung darat. Selain itu juga dapat meningkatkan jumlah daun serta tinggi batang kangkung darat. Aplikasi pupuk NPK 1,5 gram per tanaman adalah perlakuan optimal untuk memacu pertumbuhan kangkung darat yang menghasilkan panjang daun $=140 \mathrm{~mm}$, lebar daun $=36 \mathrm{~mm}$, jumlah daun $=9$ helai serta tinggi batang tertinggi mencapai $24 \mathrm{~cm}$ (Raksun et al, 2020). Aplikasi pupuk NPK dapat meningkatkan pertumbuhan sawi 
sendok. Perlakuan 2 gram pupuk NPK per tanaman menimbulkan pertumbuhan sawi sendok yang lebih baik dari pada perlakuan pupuk NPK pada dosis yang lainnya (Raksun et al, 2020). Penelitiaan pada tanaman jagung manis diperoleh hasil bahwa aplikasi pupuk NPK dapat meningkatan panjang daun, jagung manis. Aplikasi 6 gram pupuk NPK per tanaman merupakaan perlakuan terbaik untuk meningkatkan pertumbuhan jagung manis (Raksun et al, 2021).

\section{Tinggi Batang}

Tinggi batang tanaman terung hijau berbeda beda pada stiap unit perlakuan. Secara umum tinggi batang mengalami peningkatan seiring dengan meningkatnya kadar kascing dan pupuk NPK yang diaplikasikan. Ukuran tinggi maksimum adalah 84 $\mathrm{cm}$ dihasilkan oleh aplikasi 2 gram pupuk NPK per tanaman dan $1,8 \mathrm{~kg}$ pupuk kascing per $1 \mathrm{~m}^{2}$ lahan pertanian. Data ukuran batang tinggi batang terung hijau terendah sebesar $75 \mathrm{~cm}$ diperoleh pada tanaman terung hijau tanpa pemberian pupuk NPK dan pupuk kascing. Data ukuran batang terung hijau setelah perlakuan pupuk NPK dan kascing dapat dilihat pada tabel 4 .

Tabel 4. Data Tinggi Batang Terung Hijau Setelah Perlakuan yang Diukur 60 HST

\begin{tabular}{|c|c|c|c|}
\hline Kombinasi & $\begin{array}{c}\text { Tinggi Batang } \\
(\mathrm{cm})\end{array}$ & Kombinasi & $\begin{array}{l}\text { Tinggi Batang } \\
(\mathrm{cm})\end{array}$ \\
\hline NoK0 & 75 & $\mathrm{~N}_{2} \mathrm{~K} 0$ & 77 \\
\hline NoK1 & 76 & $\mathrm{~N}_{2} \mathrm{~K}_{1}$ & 78 \\
\hline $\mathrm{N}_{0} \mathrm{~K}_{2}$ & 77 & $\mathrm{~N}_{2} \mathrm{~K}_{2}$ & 79 \\
\hline $\mathrm{N}_{0 \mathrm{~K} 3}$ & 78 & $\mathrm{~N}_{2} \mathrm{~K} 3$ & 84 \\
\hline NoK4 & 76 & N2K4 & 82 \\
\hline $\mathrm{N}_{1} \mathrm{~K}_{0}$ & 76 & $\mathrm{~N}_{3} \mathrm{~K}_{0}$ & 74 \\
\hline $\mathrm{N} 1 \mathrm{~K}_{1}$ & 77 & N3K 1 & 76 \\
\hline $\mathrm{N} 1 \mathrm{~K} 2$ & 78 & N3K2 & 76 \\
\hline N1K3 & 79 & N3K3 & 78 \\
\hline N1K4 & 77 & N3K4 & 76 \\
\hline
\end{tabular}

Uji Anova memberikan hasil bahwa aplikasi kascing berdampak signifikan pada peningkatan ukuran batang tanaman terung hijau. Perlakuan pupuk NPK berdampak signifikan pada peningkatan ukuran batang tanaman terung hijau. Ukuran batang tidak berbeda nyata akibat interaksi perlakuan pupuk NPK dan kascing. Hasil yang srupa diperoleh pada taanamaan lain. Penilitian pada tanaman sawi memberikan hasil bahwa perlakuan pupuk kascing dapat meningkatkan tinggi tanaman sawi umur 9 sampai dengan 29 hari setelah tanam. Tinggi tanaman maksimum adalah $18,6 \mathrm{~cm}$ yang diperoleh pada perlakuan 60 gram kascing. Selain itu, perlakuan pupuk kascing juga dapat meningkatkan bobot basah tanaman sebesar 10,3 gram, bobot kering tanaman sebesar 1,3 gram, bobot kering akar sebesar 0,4 gram (Pratama et al, 2018). Aplikasi pupuk kascing berdampak signifikan terhadap peningkatan tinggi tanaman selada, Selain itu perlakuan pupuk kascing juga mampu meningkaatkan jumlah daun dan volume tajuk tanaman selada. Kadar terbaik kascing bagi pertumbuhan selada adalah 50 gram untuk setiap polybag (Dosem et al, 2018).

Aplikasi pupuk NPK dapat meningkatkan tinggi batang terung hijau. Adanya peningkatan tinggi batang akibat perlakuan pupuk NPK juga dilaporkan oleh peneliti lain. Tinggi batang kangkung darat bertambah akibat aplikasi pupuk NPK. Kadar terbaik pupuk NPK pada kangkung darat sebesar 1,5 gram untuk 1 batang, yang menghasilkan tinggi batang tertinggi mencapai 24 cm (Raksun et al, 2020). Aplikasi pupuk NPK mutiara berdampak signifikan terhadap panjang tanaman kacang panjang. Perlakuan 1 gram per liter menghasilkan panjang tanaman paling tinggi sebesar $322 \mathrm{~cm}$. Panjang tanaman paling rendah terdapat pada tanaman control 282,6 cm (Oktaviani et al, 2017). Perlakuan pupuk NPK dapat meningkatkan panjang tanaman kacang panjang. Perlakuan terbaik adalah $150 \mathrm{~kg}$ per hektar menghasilkan tanaman 160,63 cm (Purwanto et al, 
2019) Aplikasi pupuk NPK dapat meningkat tinggi tanaman dan berat kering tajuk Shorea laevis. Perlakuan terbaik pupuk NPK sebesar 2 g pupuk NPK per tumbuhan (Handayani dan Apriani, 2020).

\section{Kesimpulan}

Dalam penelitian ini disimpulkan: (1) perlakuan pupuk NPK dengan dosis yang berbedabeda berpengaruh signifikan terhadap jumlah daun, diameter batang., panjang daun dan tinggi batang tanaman terung hijau, Dosis terbaik pupuk NPK adalah 2 gram per tanaman yang menghasilkan jumlah daun, diameter batang, panjang daun dan tinggi tanaman terung hijau yang lebih baik daripada perlakuan pada dosis yang lain, (2) Aplikasi kascing berdampak signifikan pada peningkatan jumlah daun, diameter batang, panjang helaian daun dan tinggi tanaman terung hijau, dosis optimum pupuk kascing adalah 18 ton kascing utuk 1 hektar sawah, menghasilkan parameter pertumbuhan terung hijau yang lebih baik daripada dosis yang lain. (3) interaksi kascing dan pupuk NPK tidak berdampak signifikan terhadap diameter batang, jumlah daun, panjang daun dan tinggi batang tanaman terung hijau.

\section{Ucapan Terima kasih}

Kepada Rektor Universitas Mataram, kami ucapkan termakasih yang tiada terhingga atas penyediaan Dana untuk pelaksanaan penelitian. Demikian juga untuk saudara-saudara yang telah mendukung terlaksananya penelitian ini, kami sampaikan terima kasih yang tiada terhingga.

\section{References}

Adnan, I.S., Utoyo, B. \& Kusumastuti, A. (2015). Pengaruh Pupuk NPK dan Pupuk Organik terhadap Pertumbuhan Bibit Kelapa Sawit (Elaeis guineensis Jacq) di Main Nursery. Agro Industri Perkebunan. 3(2): 69 - 81.

Afandi, F.N., Siswanto, B \& Nuraini, Y. (2015). Pengaruh Pemberian Berbagai Jenis Bahan Organik terhadaap Sifat Kimia Tanah pada Pertumbuhan dan Produksi Tanaman Ubi Jalar di Entisol Ngrangkah Pawon Kediri. Jurnal Tanah dan Sumberdaya Lahan. 2(1): 237
244

Aidah, S.N. (2020). Ensiklopedi Terong, Deskripsi, Filosofi, Manfaat, Budidaya dan Peluang Bisnisnya. KBM Indonesia. Jokjakarta.

Assagaf, S.A.R. (2017). Pengaruh Pemberian Pupuk NPK Mutiara terhadap Pertumbuhan dan Produksi Tanaman Jagung. Jurnal Ilmiah Jurnal Agribisnis dan Perikanan. 10(1): 72 78.

Astuti, D.A., Sudarsono, Sulaeman, \& A. Syukur, M. 2016. Pertanian Organik di Indonesia. IPB Press. Bogor.

Ayu, J., Sabli, E. \& Sulhaswardi. (2017). Uji Pemberian Pupuk NPK Mutiara dan Pupuk Organik Cair Nasa terhadap Pertumbuhan dan Hasil Tanaman Melon (Cucumis melo L.) Jurnal Dinamika Pertanian. 33(1): 103 114.

Cahyono, E.G., Ardian \& Silvina, F. (2014). Pengaruh Pemberian Beberapa Dosis Pupuk NPK terhadap Pertumbuhan Berbagai Sumber Tunas Tanaman Nanas (Annanas comosus L. merr) yang Ditanam Antara Tanaman Kelapa sawit Belum Menghasilkan di Lahan Gambut. Jom Faperta. 1(2): 1 - 13.

Dosem, I.R., Astuti, Y.T.M. \& Santosa, T.N.B. (2018). Pengaruh Dosis Pupuk Kascing dan Volume Penyiraman terhadap Hasil Tanaman Selada (Lactuca sativa). Jurnal Agromast. 3(1): $1-11$.

Elfayetti, Sintong, M., Pinem, K. \& Primawati, L. (2017). Analisis Kadar Hara Pupuk Organik Kascing dari Limbah Kangkung dan Bayam. Jurnal Geografi. 9(1): 1 - 10.

Febians, J.D. Hitijahubessy \& Siregar, A. (2016). Peranan Bahan Organik dan Pupuk Majemuk NPK dalam Menentukan Percepatan Pertumbuhan Tanaman Jagung (Zea mays saccharata L.) pada Tanah Inceptisol (Suatu kajian Analisis Pertumbuhan Tanaman). Jurnal Budidaya Pertanian. 12(1): 1 - 9. 
Firmansyah, I., Syakir, M. \& Lukman, L. (2017). Pengaruh Kombinasi Dosis Pupuk N, P dan K terhadap Pertumbuhan dan Hasil Tanaman Terung (Solanum melongena L.) J. Hort. 27(1): $69-78$.

Gomez K.A. \& A.A. Gomez. (1991). Prosedur Statistik Untuk penelitian Pertanian. Edisi Kedua Penerjemah: Endang Syamsudin dan Justika S. Baharsyah. UI Press. Jakarta.

Gusmini, Yulnafatmawita \& A.F. Daulay (2008). Pengaruh Pemberian Beberapa Jenis Bahan Organik terhadap Peningkatan Kandungan Hara N, P dan K Ultisol Kebun Percobaan Paperta Unad Padang. J. Solum, 5 (2): 57 65.

Handayani, R. and Apriani, H. (2020). Effect of NPK Fertilizer and Planting Media on The growth and Production of Shorea laevis Ridl. Jurnal Penelitian Ekosistem Dipterokarpa. 6(2): $107-116$.

Hidayatullah, W., Rosmawaty, T. \& Nur, M. (2020). Pengaruh pemberian Pupuk Kascing dan NPK Mutiara 16:16:16 terhadap Pertumbuhan dan Hasil Okra (Albelmoschus esculentus L. Moenc) serta Bawang Merah (Alium ascalonicum L.) dengan Sistem Tumpang Sari. Dinamika Pertanian. 36(1): $11-20$.

Irawan, S., Safruddin \& Marwani, R. (2019). Pengaruh Perlakuan Jarak Tanam dan Pupuk NPK terhadap Pertumbuhan dan Produksi Tanaman Jagung (Zea mays L) BERNAS Agricultural Research Journal. 15(1): 174 184.

Khairani, I., Hartati, S. \& Mujiono. (2010). Pengaruh Kascing dan Pupuk Anorganik terhadap ketersediaan nitrogen pada Alfisols dan serapannya oleh tanaman jagung manis (Zea mays L. saccharata). Ilmu Tanah dan Agroklimatologi. 7(20: $73-81$.

Maghfoer, M.D. (2018). Tekhnik Pemupukan Terung Ramah Lingkungan. UB. Press. Malang.
Manahan, S., Idwar \& Wardati (2016). Pengaruh Pupuk NPK dan Kascing terhadap Pertumbuhan kelapa Sawit (Elaeis Guineensis Jacq) fase main Nusery. JOM Faperta 3(2): 1 - 10.

Mashudi (2007). Budidaya Terung Azka Prees. Bekasi.

Mulat, T. (2003). Membuat dan Memanfaatkan Kascing Pupuk Organik Berkualitas. AgroMedia Pustaka. Jakarta.

Murdaningsih and Kramat, A.B. (2014). The Effect of Doses of NPK Fertilizer OnThe Growth and yield of Green Bean (Phaseolus radiates L.). Agrica. 7(1): $45-56$.

Oktaviani, A., Izzati, M. \& Parman, S. (2017). Pengaruh Pupuk kandang dan NPK Mutiara terhadap Pertumbuhan dan Produksi Kacang Panjang. Buletin Anatomi dan Fisiologi. 2(2): $236-241$.

Pratama, T.Y., Nurmayulis \& Rohmawati, I. (2018). Tanggapan Beberapa Dosis Pupuk Organik Kascing terhadap Pertumbuhan dan Hasil Tanaman Sawi (Brassica juncea L) yang Berbeda Varietas. Agrologia. 7(2):81 - 89.

Raksun, A., Mahrus \& Mertha, I.G. (2020). Vegetative Growth of Kale Land (Ipomoea reptans poir.) Due to Different Doses of NPK and Bokashi Fertilizer. Biologi Tropis. 20 (2): $305-313$.

Raksun, A., Ilhamdi, M.L., Merta, I.W. \& Mertha, I.G. (2020). Vegetative Growth of Pakcoy (Brassica rapa L.) Due to Different Dose of Bokashi and NPK Fertilizer Biologi Tropis. 20 (3): $452-459$.

Raksun, A., Merta, I.W. Mertha, I.G. \& Ilhamdi, M.L. (2021). Response of Sweet Corn (Zea mays L. Sccharata) Growth on the Treatment of Organic and NPK Fertilizer. Biologi Tropis. 21 (1): $131-139$.

Sinda, K.M.N.K., Kartini, N. \& Atmaa, I.W.D. (2015). Pengaruh Dosis Pupuk Kascing terhadap Hasil Tanaman Sawi (Brassica 
juncea L.) Sifat Kimia dan Biologi pada Tanah Inceptisol Klungkung. E-Jurnal Agroteknologi Tropika. 4(3): 170 - 179.

Teutenburg, H. and Shalabh. (2009). Statistical Analysis of Designed Experiment. Third Edition. Springer. New York.
Wahyudin, S. \& Irawan, A.W. (2019). Pengaruh Dosis Kascing dan Bioaktivator terhadap Pertumbuhan dan Hasil Tanaman Sawi (Bassica juncea L.) yang Dibudidayakan Secara Organik. Jurnal Kultivasi .18(2): 899 -902 . 